\title{
Erratum to: Enjoyment and Its Discontents: Ecclesiastes in Dialogue with Freud on the Stewardship of Joy
}

\section{Philip Browning Helsel}

\section{Erratum to: J Relig Health \\ DOI 10.1007/s10943-008-9224-8}

In the above mentioned article, in Freud's theory of the self section, the word topographical should read structural in the following places:

1. In the abstract (p. 1 page).

2. In the first full paragraph of p. 3 .

3. In the middle of p. 8- "topographical model of the person."

4. In the first paragraph of p. 11. "What the Freudian topographical model shows..."

The online version of the original article can be found under doi:10.1007/s10943-008-9224-8. 